\title{
Reemplazo de una pradera permanente y su efecto en el primer año en una lechería comercial
}

t.

\author{
Replacing a permanent pasture and its effect in the first year \\ on a commercial dairy farm \\ Rivero, M.J. ${ }^{a *}$, Orr, R.J. ${ }^{a}$, Coumbe, J. ${ }^{b}$, Willson, B. ${ }^{b}$ Evans, J. ${ }^{c}$ Lee, M.R.F. ${ }^{a, d}$ \\ ${ }^{a}$ Rothamsted Research, North Wyke, Okehampton, Devon, EX20 2SB, UK. \\ ${ }^{b}$ Duchy College, Stoke Climsland, Callington, Cornwall, PL17 8PB, UK. \\ ${ }^{c}$ Rothamsted Research, West Common, Harpenden, Hertfordshire, AL5 2JQ, UK. \\ ${ }^{d}$ Bristol Veterinary School, University of Bristol, Langford, Somerset, BS40 5DU, UK.
}

\begin{tabular}{l} 
A R T I C L E I N F O \\
\hline Article history: \\
Received: 23.04 .2018 \\
Accepted: 07.06.2018 \\
\hline Keywords: \\
High sugar grass \\
Permanent pasture \\
Grazing dairy systems \\
Milk composition \\
Milk yield \\
\hline Original Research Article, \\
Animal Science \\
\hline *Corresponding author: \\
Jordana Rivero \\
E-mail address: \\
jordana.rivero-viera@rothamsted.ac.uk
\end{tabular}

\begin{abstract}
A B S T R A C T
The objective was to assess the impact of replacing a permanent pasture with a reseeded pasture on system productivity and product quality in the first year of establishment under commercial conditions management. Dairy cows were allocated to treatment based on pasture availability at the start of the season following standard commercial practices. Seventy autumn-calved cows grazed a high sugar grass pasture (14.1 ha reseeded in September 2015) and 55 grazed a permanent pasture (12.1 ha) from April to June 2016. Pastures snip samples were taken to assess nutritional composition every two weeks. Milk production and composition was measured on $4^{\text {th }}$ May and $10^{\text {th }}$ June. A slightly higher content of water soluble carbohydrate was observed in May on the reseeded sward ( 27.1 vs. $25.8 \%$ ) coinciding with a higher milk yield ( 24.6 vs. $22.9 \mathrm{~L} \mathrm{~d}^{-1}$ per cow), lactose content (4.41 vs. $4.34 \%$ ), and a lower somatic cell account (59,400 vs. 113,300 cell $\left.\mathrm{mL}^{-1}\right)$, compared to the permanent pasture. Pasture varied in nutritional value across the study. In June, no differences in milk production or composition were observed. However, the reseeded sward was estimated to produce $12.3 \%$ more milk per ha than the permanent pasture during the experimental period (113.8 vs. $101.3 \mathrm{~L} \mathrm{ha}^{-1} \mathrm{~d}^{-1}$ ), driven by the greater carrying capacity of the sward ( 5 vs. $4.5 \mathrm{LU} \mathrm{ha}^{-1}$ ). This farm case study shows the potential of a reseeded pasture to outperform permanent pasture even in the first year of establishment at a farm system scale.
\end{abstract}

\section{RESUMEN}

El objetivo fue evaluar el impacto de reemplazar una pradera permanente con una sembrada en la productividad del sistema y la calidad del producto en el primer año de establecimiento en condiciones comerciales de manejo. Las vacas lecheras fueron asignadas a los tratamientos en base a la disponibilidad de pradera al comienzo de la temporada siguiendo las prácticas comerciales estándar. Setenta vacas de parto de otoño pastorearon una pradera de ballica perenne de un cultivar alto en azúcar $(14,1$ ha sembrada en septiembre 2015) y 55 pastorearon una pradera permanente $(12,1$ ha) desde abril a junio 2016 . Las praderas fueron muestreadas para evaluar la composición nutricional cada dos semanas. La producción y composición de la leche fue medida el 4 de mayo y 10 de junio. Un leve mayor contenido de carbohidratos solubles fue observado en mayo en la pradera sembrada (27,1 vs. $25,8 \%$ ) coincidiendo con una mayor producción de leche $\left(24,6\right.$ vs. 22,9 L d ${ }^{-1}$ por vaca), contenido de lactosa (4,41 vs. 4,34\%), y menor recuento de células somáticas (59.400 vs. 113.300 células $\mathrm{mL}^{-1}$ ), comparado con las vacas de la pradera permanente. Las praderas variaron en composición nutricional a lo largo del estudio. En junio no se observaron diferencias en la producción o composición de la leche. Sin embargo, se estimó que la pradera sembrada produjo un 12,3\% más leche por hectárea que la pradera permanente durante el periodo experimental (113,8 vs. 101,3 L ha-1 $\left.\mathrm{d}^{-1}\right)$, generado por la mayor carga animal soportada (5 vs. 4,5 UG ha-1). Este estudio de caso muestra el potencial de una pradera sembrada para superar el desempeño de una pradera permanente en el primer año de establecimiento a nivel de predio.

Palabras clave: ballicas altas en azúcar, pradera permanente, sistemas pastoriles lecheros, composición de la leche, producción de leche. 


\section{INTRODUCTION}

World population is expected to increase to circa 9 billion by 2050 with an increasingly wealthy and urbanised society. Hence, the challenge for future agriculture will be to increase food production by $70 \%$ (FAO, 2009), without destroying the environment. Production intensification is therefore required because expansion of agricultural area as a response is not desirable (Pretty and Bharucha, 2014). At the same time, soil and water resources for agriculture are increasingly in short supply and degraded. Therefore, the increase in food production must be reached through a sustainable intensification (SI) process, i.e., producing more with less.

Even though cattle are responsible for $2 / 3$ of livestock associated emissions $(F A O, 2009)$ they play a positive role in global food systems by providing: high quality protein-rich food for humans, recycling biomass from inedible resources or utilising lands that are not suitable for growing crops for humans, and improving soil health through organic matter returns (Eisler et al., 2014).

When permanent pasture (PP) decline in yield (pasture performance e.g. pasture yield - kg Dry Matter (DM) ha ${ }^{-1}$, animal yield - litres of milk per lactation) or utilised output (e.g. carrying capacity ( $\left(\mathrm{LU} \mathrm{ha}^{-1}\right)$ ), farmers are motivated to renovate or reseed grasslands. This reduced performance is often associated with the botanical composition where the desirable species of the sward has decreased, e.g. proportion of perennial ryegrass (Lolium perenne L.) is less than 50\% (Søegaard et al., 2007). The sown species is preferred due to its greater nutritional value and therefore potential for increasing production and decreasing the negative unintended consequences (nutrients loss to water contamination or greenhouse gas (GHG) emissions) through improving nutrient use efficiency, particularly $\mathrm{N}$ use efficiency (NUE). In grazing systems, NUE can be improved by increasing the water-soluble carbohydrate (WSC) content of forage with an expected increase in milk yield per cow and simultaneously reduced release of labile-N (urine) to the environment (Lee et al., 2018). For this purpose, high sugar grass (HSG) cultivars of $L$. perenne have been developed in the UK as an approach to increase efficiency of grazing systems. However, making the decision to reseed is a balance between potential future benefits of improved animal performance, driven by improved DM yield and pasture quality, and loss of grazing area plus potential risk of poor yields during first year after establishment. Therefore, the objective of this study was to assess the effect of replacing permanent pasture with HSG reseed on pasture performance, dairy cows productivity and product quality in the first year after establishment with the grazing management based on commercial decisions at a farm system level.

\section{MATERIAL AND METHODS}

The effect of two different pastures on pasture performance, animal productivity and product quality of autumn calving dairy cows was compared in a grazing experiment during spring 2016 at Future Farm, Duchy College, Stoke Climsland, Cornwall, UK.

\section{Pasture establishment}

Two fields (collectively 14.1 ha) were ploughed and reseeded with a high sugar perennial ryegrass, cultivar AberMagic, in September 2015. The PP treatment comprised of five fields totaling 12.1 ha and had not been reseeded for minimum of 5 years. Before reseeding, pastures were similar in age and use.

Lime was applied on HSG fields at a rate of 5-7 $\mathrm{t} \mathrm{ha}^{-1}$ to keep pH at 6, and $15 \mathrm{~m}^{3} \mathrm{ha}^{-1}$ slurry was applied over the winter (January 2016). No lime was required based on soil $\mathrm{pH}$ for the PP fields (all fields with $\mathrm{pH}$ between 6 and 6.4).

Regarding $\mathrm{N}$ fertilization, $40 \mathrm{~kg} \mathrm{~N}^{-1}$ (urea) was applied to all trial fields as soon as the ground permitted (end of February 2016). Then $36 \mathrm{~kg} \mathrm{~N} \mathrm{ha}^{-1}$ (ammonium nitrate) were applied in spring in each field (AprilMay), totalling $76 \mathrm{~kg} \mathrm{~N} \mathrm{ha}^{-1}$ during the experimental period. All fields in the trial had the same amount of fertiliser applied to them by area.

\section{Cows allocation}

An autumn calving group of Holstein-Friesian dairy cows (125 cows, majority calved September 2015) were used for the trial with the cows split into two mini herds and balanced according to milk yield and milk components. Cows were condition scored on the $9^{\text {th }}$ March to define their initial body condition. Additionally, the milk yield and milk composition data required for pre-experimental analysis came from a milk recording carried out on $8^{\text {th }}$ April 2016. After that, the cows were milk recorded on May and June for the trial period. Milk recording meters were retrofitted to the parlour to complete the recording.

The data was collected over two consecutive milkings (am and pm). Cattle numbers and size of the two trial herds was driven by pasture availability at the start of the trial, 55 cows were allocated to the PP group and 70 cows were allocated to the HSG reseeded sward group. The decision to allocate based on a commercial assessment of pasture availability was taken to best mimic the approach that would be taken by the industry. Allocation of animals was balanced according to milk yield and milk components from the previous milking but we also investigated the potential impact of body condition score (BCS) and lactation number on milk quality and yield within the study, but did not allocate on these assessments. 


\section{Grazing management and feeding regime}

Cows were housed day and night before turn-out on to the experimental pastures in April. During the housing period, all cows received the same daily diet on a fresh weight basis: home-grown grass silage $27 \mathrm{~kg}$, home-grown maize (Zea mays L.) silage $22 \mathrm{~kg}$, 28\% crude protein nuts (Molemax HF 28 nuts, Mole Valley Feed Solutions Ltd., UK) $3.5 \mathrm{~kg}$, barley (Hordeum vulgare L.) straw $1 \mathrm{~kg}$, crimped wheat (Triticum aestivum L.) $1 \mathrm{~kg}$, farm pack minerals $300 \mathrm{~g}$, limestone $200 \mathrm{~g}$, urea $100 \mathrm{~g}$, and combi buff $150 \mathrm{~g}$ (Mole Valley Feed Solutions Ltd.).

Cows were turned-out on April $18^{\text {th }}$ to their experimental fields as indicated above. From April $18^{\text {th }}$ to May $3^{\text {rd }}$ cows were housed at night and receiving the same daily buffer diet: home-grown grass silage $9 \mathrm{~kg}$, home-grown maize silage $9 \mathrm{~kg}$, 28\% crude protein nuts $1 \mathrm{~kg}$, barley straw $1 \mathrm{~kg}$, crimped wheat $1 \mathrm{~kg}$, farm pack minerals $300 \mathrm{~g}$, limestone $200 \mathrm{~g}$, combi buff $150 \mathrm{~g}$, with all feed ingredients sourced from the same manufacturers as during the housing period. From May $4^{\text {th }}$ the buffer diet was stopped, and cows were turnedout for day and night, only returning to the parlour at milking. In parlour cows received $2 \mathrm{~kg}$ of cake per day distributed over the 2 milkings. An 18\% crude protein nut (New Formula Gold HDF 18 nuts, Mole Valley Feed Solutions Ltd.) was used in parlour until end of April 2016 and then replaced with a 16\% crude protein nut (Grasslink Formula Gold HDF 16 nuts, Mole Valley Feed Solutions Ltd.) until the end of the trial.

During the grazing period, cows rotationally grazed and were moved to an area of fresh pasture (size determined by herdsman and grass growth) every 24 $h$. The paddocks were divided up with electric fencing and back-fenced with ad libitum access to water. The PP and HSG fields were grazed (and treated) in the same way and the area in which each group was grazing each day was recorded. If an excess of grass occurred, this excess was cut for silage, and the total area of the field that was cut was recorded along with the total dry matter that was removed.

\section{Sampling and measurements}

The trial ran from $18^{\text {th }}$ April to $10^{\text {th }}$ June after which the cows were dried off (according to calving date). Meteorological data was obtained from a weather station on site to coincide with the trial period.

Milk yields were recorded over the trial period with milk samples taken on $5^{\text {th }}$ April (used as the pre-experimental data), $4^{\text {th }}$ May, and $10^{\text {th }}$ June. On these dates one sample was taken per cow and analysed for quality (protein, butterfat, lactose, SCC) using CombiFoss ${ }^{\mathrm{TM}}$ FT+ at CIS laboratory (Telford, UK).

Herbage samples were collected on $8^{\text {th }}$ April, $19^{\text {th }}$ April, $3^{\text {rd }}$ May, $17^{\text {th }}$ May, and $8^{\text {th }}$ June. In each sampling time, three bulked snip samples ( $\mathrm{n}=3$ per sward type) were taken within three ' $W$ ' transects (five sample points per W transect) from each of the two fields where cows were grazing (HSG and PP). Each sample yielded approximately $300 \mathrm{~g}$ fresh weight and was sent to Rothamsted Research North Wyke lab in a cool box prior to freezing and freeze-drying before analysis.

WSC content was quantified using the methods of Thomas (1977). Fibre fractions, i.e., Acid Detergent Fibre (ADF), modified Acid Detergent Fibre (mADF) and Neutral Detergent Fibre (NDF) were quantified using a FOSS Fibertec 8000 Auto Fiber Analysis System (AOAC, 1990 and 2002). Metabolisable Energy (ME) was obtained from $\mathrm{mADF}$ fractions using equations calibrated for UK pastures (Alderman and Cottrill, 1993). Total N contents were measured using an elemental analyser and isotope ratio mass spectrometer, and crude protein (CP) content was obtained from multiplying total $\mathrm{N}$ by a factor of 6.25 .

\section{Data analysis}

The treatments compared were PP (55 cows) vs. HSG pastures (70 cows). Other explanatory factors included were lactation number $(1,2,3,4,5+)$ and BCS $(2,2.5,3,3.5+$, in a scale from 1 to 5$)$ of the cows. The response variables were milk yield (MY), milk fat content (MF), milk protein content (MP), milk lactose content (ML) and somatic cell count (SCC) at three-time points (pre-experimental period (April), and two measurements (May and June) during the experimental period). Pre-experimental MY, MF, MP, ML and SCC were considered covariates.

Each response and time point was analysed separately using linear mixed models to allow for the imbalance in animal numbers assigned to each pasture type (driven by pasture production differences) and the imbalance in the explanatory factors between groups (lactation number and BCS). 'Cow' was used as the random term in the model to allow for the fact that individual cows were considered as replicates (despite treatment being applied at herd level).

Prior to the main analysis, pre-experimental values of MY, MF, MP, ML and SCC were analysed to look for differences/trends due to treatment, lactation or BCS of the experimental cows. The lack of any treatment differences in the pre-experimental period meant that these pre-experimental values could be used as covariates in the main analysis described above.

Explanatory terms were fitted in order treatment*lactation*condition (after the relevant preexperimental covariate was included) and an appropriate model was chosen using backward selection but keeping main effect of treatment.

Somatic cell count required a log transformation (base 10) in order to meet the assumptions of the analysis. 
For analysing nutritional value of the pasture (response variables: WSC, CP, WSC to CP ratio, DM, ADF, NDF, ME and total ash), a two-way $(2 \times 5)$ analysis of variance was carried out including as source of variation the main factors sward type (HSG vs. PP) and sampling period (five sampling periods) as fixed effects, and their interactions, with three replicates per sward per period.

The Genstat ${ }^{\circledR}$ (@) VSN International Ltd., UK) statistical system was used for the analysis.

\section{RESULTS AND DISCUSSION}

\section{Weather data}

Table 1 shows a summary of weather parameters recorded at Future Farm from March to June. Even though March was not part of the experimental period (grazing season), weather conditions in this month influenced the decision on when the animals could be turned out given their effect on pasture growth and soil humidity. The total rainfall accumulated for the grazing months was $176 \mathrm{~mm}$. Mean air temperature ranged from $6.1^{\circ} \mathrm{C}$ in March to $14.6^{\circ} \mathrm{C}$ in June 2016 .

March was rainy and cold, and April was also cold. This cool temperature during early spring caused the cows to be turned out later than expected due to the slow pasture growth. However, May and June were mild months. The marked increase in air temperature and solar radiation from April to May allowed a good growth of the swards.

\section{Pasture quality}

The main effect of sward type was significant for most of the response variables analysed in pasture: DM percentage, WSC, CP and ash contents, and WSC to $\mathrm{CP}$ ratio (Table 2). Moreover, the effect of the sampling period was highly significant for all the variables $(p<0.001)$; WSC concentration increased in spring and then decreased towards summer, whilst $\mathrm{CP}$ had the opposite pattern (Figure 1).

\section{WSC and CP concentrations}

The variations in WSC content among sample dates observed in this study have already been reported for HSG (Parsons et al., 2004; Moorby et al., 2006) and for CP (McGrath, 1992). However, there were some significant interaction effects also for: WSC, CP, NDF, DM, ME, ash, and WSC to CP ratio (Table 2).

$\mathrm{CP}$ was higher for PP from the beginning of the sampling period (Figure 1a), and particularly at the beginning of the grazing period (P2), with an average CP content of $21.0 \%$ compared with $18.8 \%$ for HSG LSD $_{0.05}$ $=0.482$ ). However, at the end of the experiment, the $\mathrm{CP}$ content of the swards switched, resulting in a higher CP on the HSG pasture than PP (27.4 vs. 17.6\%). A similar variation across sampling periods was observed for WSC content where PP showed higher values than HSG for P1 and P2. Then HSG was higher than PP (27.1 vs. $25.8 \%)$ in P3, with no difference observed in P4 LSD $_{0.05}$ $=0.619$; Figure 1b). However, in P5 PP notable surpassed WSC of HSG, which is an unexpected result, given that high sugar grasses were developed to contain more WSC than standard cultivars (Humphreys, 1989).

This remarkable increase in CP and decrease in WSC of the HSG at the end of the experiment resulted in a WSC to CP ratio of 0.4 (Figure 1c). Pacheco et al. (2007) indicates that benefits of high WSC concentrations for increasing NUE are more likely to occur when the WSC to $\mathrm{CP}$ ratio in the fresh forage diet is above 0.75 . The last sampling of the HSG sward was the only time where either of the experimental swards was observed to be below that critical level. This would suggest that the PP was of high quality in terms of nutrient provision and the HSG sward provided no improvement in terms of pasture quality and NUE.

This opposite trend in WSC and CP content agrees with a previously reported inverse relation between these components (McGrath, 1992), and a strong negative correlation was found in this study $(r=-0.75$, Figure 1d), although the relationship looks stronger for the HSG than the PP.

Table 1. Mean wind speed, relative humidity, solar radiation and air temperature, and total monthly rainfall from March 2016 to June 2016 at Future Farm (Duchy College, Cornwall).

Cuadro 1. Velocidad del viento promedio, humedad relativa, radiación solar, temperatura del aire, y precipitación mensual total de Marzo 2016 a Junio 2016 en Future Farm (Duchy College, Cornwall).

\begin{tabular}{lccccc}
\hline & Wind speed $\left(\mathrm{km} \mathrm{h}^{-1}\right)$ & Relative Humidity $(\%)$ & Rainfall $($ total, $\mathrm{mm})$ & Solar radiation $\left(\mathrm{W} \mathrm{m}^{-2}\right)$ & Air Temperature $\left({ }^{\circ} \mathrm{C}\right)$ \\
\hline March & 7.5 & 87.7 & 107.4 & 117.5 & 6.1 \\
April & 7.2 & 85.6 & 42.0 & 171.0 & 7.6 \\
May & 5.2 & 87.5 & 54.6 & 210.1 & 12.2 \\
June & 4.4 & 93.0 & 79.4 & 192.7 & 14.6 \\
\hline
\end{tabular}


Table 2. Output of the factorial ANOVA ( $\mathrm{p}$ values) for the effect of the sward type, sampling period and the interaction between main effects. All means are percentages unless stated.

Cuadro 2. Salida del ANOVA factorial (valor-p) para efecto del tipo de pradera, periodo de muestreo y la interacción entre los efectos principales. Todos los promedios son porcentajes, a menos que se indique.

\begin{tabular}{|c|c|c|c|c|c|c|}
\hline \multirow{2}{*}{ Component $^{1}$} & \multirow{2}{*}{ HSG } & \multirow{2}{*}{ PP } & \multirow{2}{*}{ s.e.m. } & \multicolumn{3}{|c|}{ Effect (P value) } \\
\hline & & & & Sward type (S) & Sampling period (P) & $\mathrm{S} \times \mathrm{P}$ \\
\hline DM & 18.28 & 20.45 & 0.150 & $<0.001$ & $<0.001$ & $<0.001$ \\
\hline WSC & 18.81 & 20.97 & 0.210 & $<0.001$ & $<0.001$ & $<0.001$ \\
\hline $\mathrm{CP}$ & 20.46 & 19.72 & 0.163 & 0.005 & $<0.001$ & $<0.001$ \\
\hline WSC/CP (ratio) & 1.009 & 1.103 & 0.021 & 0.004 & $<0.001$ & $<0.001$ \\
\hline ME (MJ kg DM"-1) & 12.77 & 12.83 & 0.088 & 0.203 & $<0.001$ & 0.020 \\
\hline NDF & 32.69 & 31.98 & 0.214 & 0.028 & $<0.001$ & $<0.001$ \\
\hline ADF & 17.16 & 16.96 & 0.212 & 0.509 & $<0.001$ & 0.054 \\
\hline Ash & 7.87 & 7.46 & 0.092 & 0.005 & $<0.001$ & $<0.001$ \\
\hline
\end{tabular}

${ }^{1}$ DM: dry matter, WSC: water soluble carbohydrates, CP: crude protein, ME: metabolisable energy, NDF: neutral detergent fibre, ADF: acid detergent fibre.

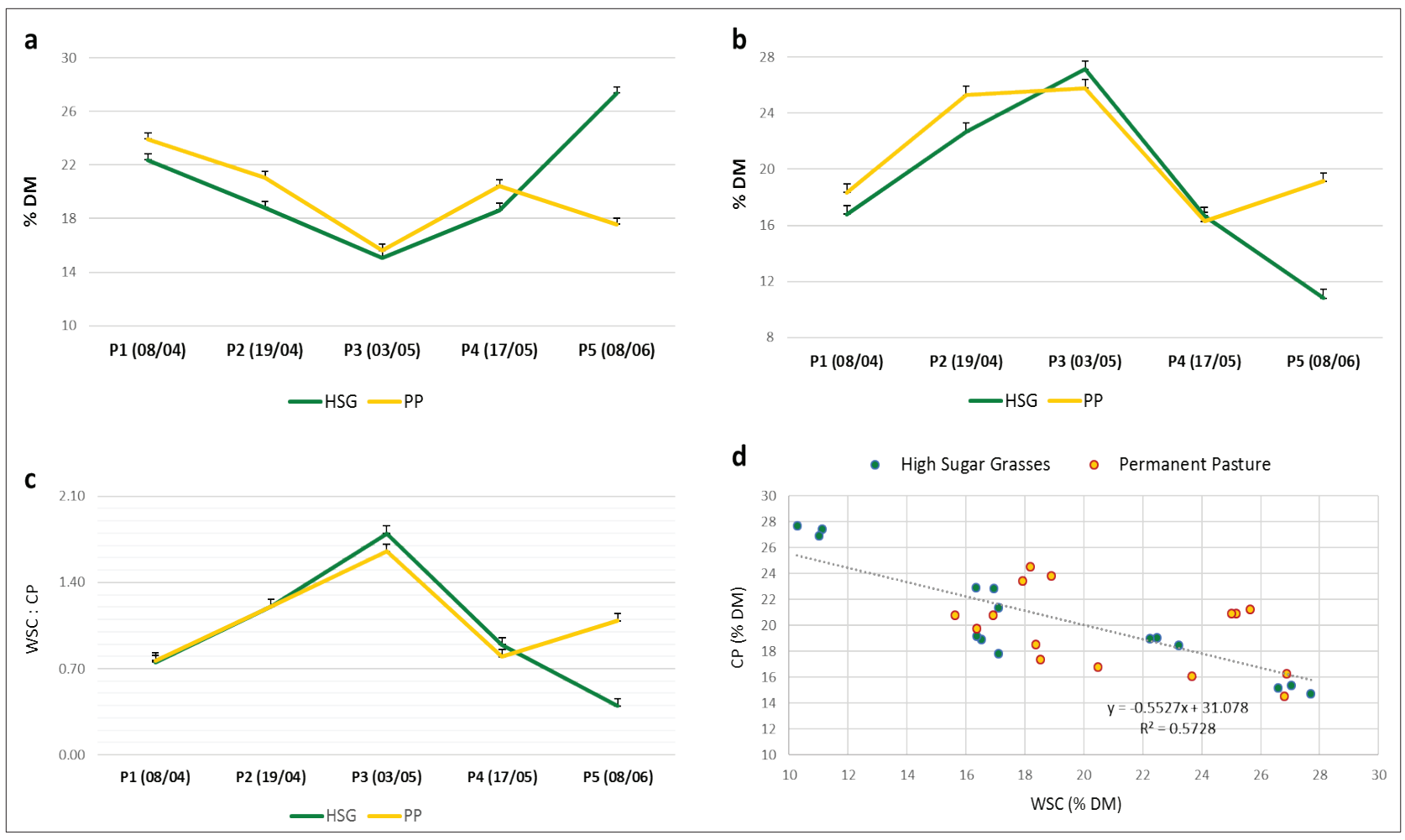

Figure 1. Nutritional value of a high sugar grass sward and a permanent pasture at Future Farm during five sampling times in April, May and June 2016 (bars are LSD $_{0.05}$ ): (a) Crude protein (\%), (b) WSC (\%), (c) WSC to CP ratio, and (d) relation between WSC and CP contents.

Figura 1. Valor nutricional de una pradera de ballica alta en azúcares y una pradera permanente en Future Farm durante cinco muestreos en abril, mayo y junio 2016 (las barras son $\mathrm{LSD}_{0,05}$ ): (a) Proteína cruda (\%), (b) WSC (\%), (c) Proporción WSC a CP, y (d) relación entre contenidos de WSC y CP. 


\section{Fibre content}

Regarding fibre components, all fractions tended to increase as the grazing season progressed. ADF had similar values in the first two samplings within sward types (HSG averaged $15.1 \%$ and PP averaged $14.65 \%$ ), and linearly increased from April $19^{\text {th }}$ until May $17^{\text {th }}$ where ADF had similar values for the two sward types $\left(\operatorname{LSD}_{0.05}=0.625\right.$, average $\left.19.6 \%\right)$ (Figure 2a). The last sampling was the only period when PP surpassed ADF content of the HSG.

NDF also increased during the experiment, and the HSG had a higher NDF content than the PP in most of the samplings (Figure 2b). However, the HSG sward had a decrease in the last sampling time, and was significantly lower than the NDF content of the PP, which is consistent with the notable increase in CP of the HSG. Pacheco et al. (2007) reported a negative association between NDF and CP, which could explain the drop in NDF with the increase in CP in the last sampling for the HSG sward and the opposite pattern in the PP. Even though NDF content was low when the cows started grazing (below $30 \%$ in P2), particularly for the PP, fibre content of forage increased consistently during the grazing period and was always situated between $30 \%$ and $40 \%$.

\section{Dry matter and ME contents}

DM content of both pastures varied notably between sampling periods, with similar trends between HSG and PP. However, at the beginning of the grazing period (P2) the PP had a greater DM content than the HSG (15.9\% vs. $25.1 \%$, Figure 2c). Total ash had similar trends between sward types except at the end of the experiment (Figure 2d).

Metabolisable energy content as expected had the opposite trend to fibre content: it decreased during the experiment from $13.26 \mathrm{MJ} \mathrm{kg} \mathrm{DM}^{-1}$ (Figure 3), which is well above the ME content for a good pasture (12.5 MJ $\mathrm{kg} \mathrm{DM}^{-1}$ ) (Waghorn and Clark, 2004), to $12.27 \mathrm{MJ} \mathrm{kg}$ $\mathrm{DM}^{-1}$.

\section{Milk yield and quality}

Average values of response variables were predicted considering the effect of the corresponding covariate values in the pre-experimental period. The effect of the explanatory variables "lactation number" and BCS on response variables are not presented nor discussed. Moreover, the interactions found between explanatory variables could be due to the unbalanced number of

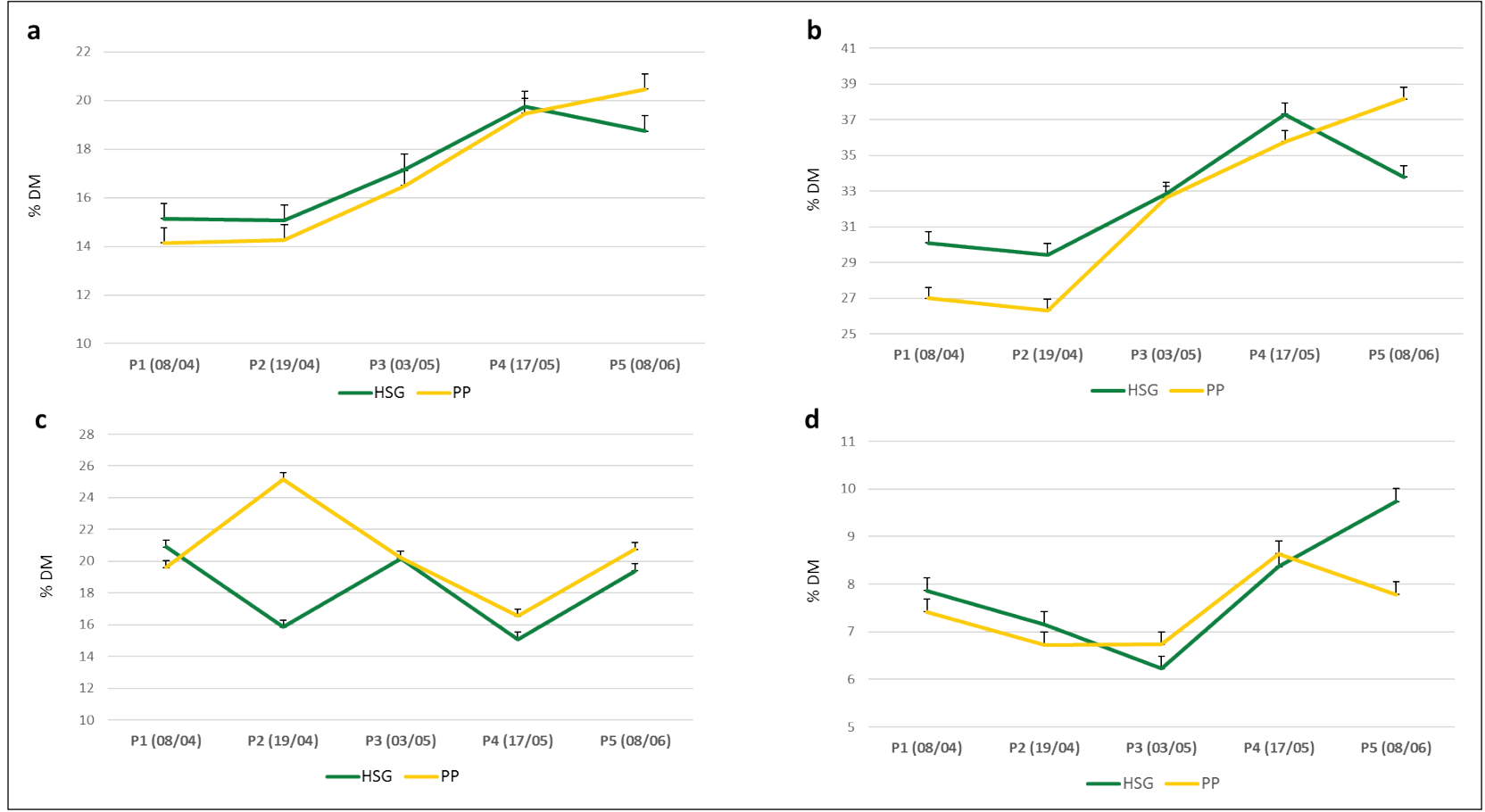

Figure 2. Nutritional value of a high sugar grass sward and a permanent pasture at Future Farm during five sampling times on April, May and June 2016 (bars are LDS $_{0.05}$ ): (a) ADF content, (b) NDF content, (c) DM content, and (d) total ash content.

Figura 2. Valor nutricional de una pradera de ballica alta en azúcares y una pradera permanente en Future Farm durante cinco muestreos en abril, mayo y junio 2016 (las barras son LSD $_{0,05}$ ): (a) contenido de FDA (\%), (b) contenido de FDN (\%), (c) contenido de MS, y (d) contenido de cenizas totales. 


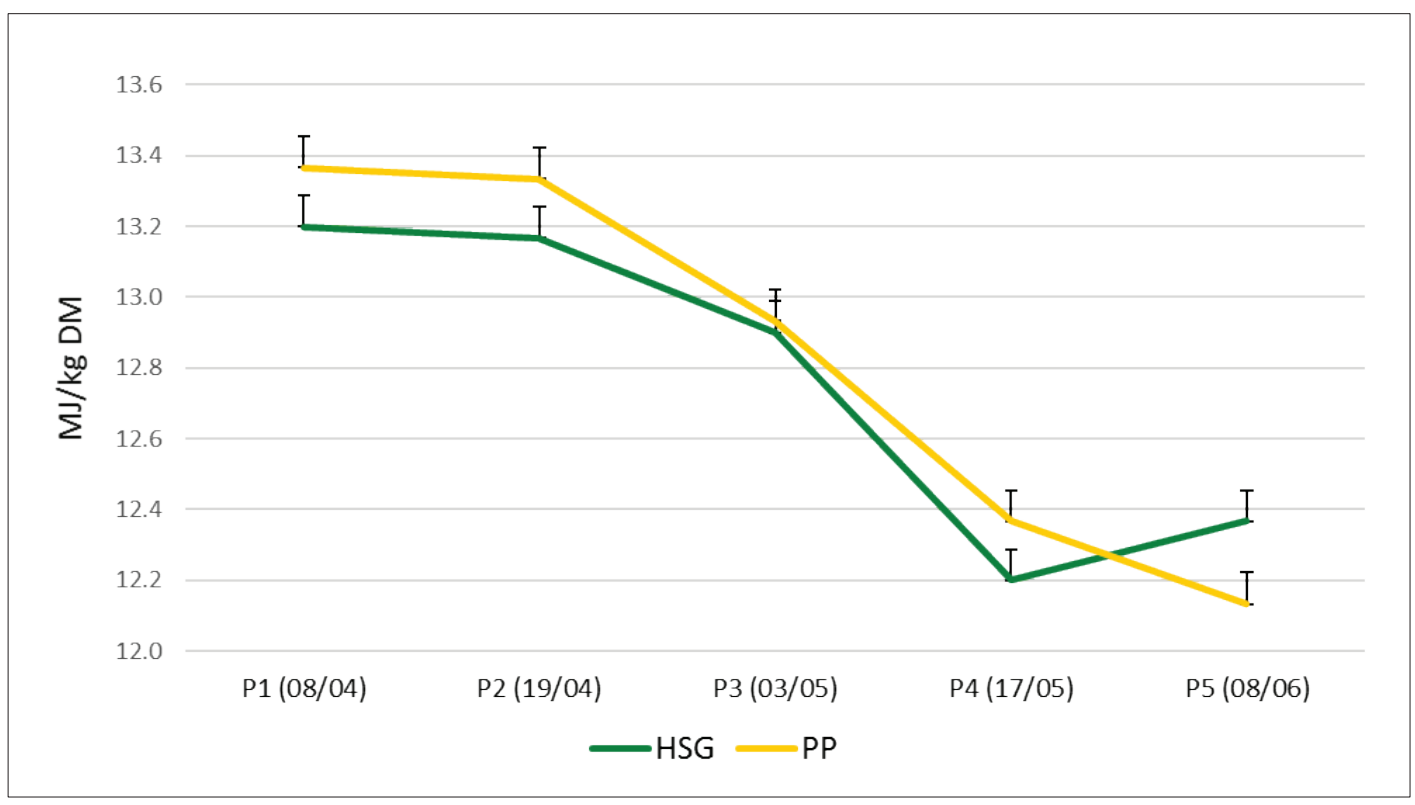

Figure 3. Metabolisable energy content of a high sugar grass sward and a permanent pasture at Future Farm during five sampling times on April, May and June 2016 (bars are LSD $_{0.05}$ ).

Figura 3. Contenido de energía metabolizable de una pradera de ballica alta en azúcares y una pradera permanente en Future Farm durante cinco muestreos en abril, mayo y junio 2016 (las barras son $\mathrm{LSD}_{0,05}$ ).

cows in each combination of BCS and lactation number. Response variables were analysed within each sampling period. In the first sampling (May) an effect of the pasture type was found significant for MY, ML and SCC. In the second sampling (June) only ML showed an effect that could be considered borderline significant (Table 3).

\section{Milk yield}

In the May sampling MY was higher (7.4\%) in the cows grazing the HSG than in the PP group (Table 3). This could be partially explained by the slightly higher WSC of the HSG $(27.1 \%$ vs. $25.8 \%)$ pasture around the sampling period and by the higher WSC to $\mathrm{CP}$ ratio $(1.80$ vs. 1.66) compared with the PP. However, Parsons et al. (2011) suggested that increasing WSC content beyond

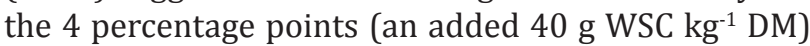
is the minimum expected to lead to a detectable significant change in animal performance, which is not the level of difference observed in the May sample (1.3 percentage points at P3). This increase in MY found here, despite the low difference in WSC content of pasture is consistent with the finding of Cosgrove et al. (2007), who reported an increase of $0.7 \mathrm{~L}$ per day (11 vs. 11.7 L) in cows grazing a HSG pasture that only surpassed a standard cultivar of perennial ryegrass pasture by 0.9 percentage points in WSC (15 vs. 15.9\%) and may be related to other aspects of digestibility (in their study
ME averaged 12.3 $\mathrm{MJ} \mathrm{kg}^{-1} \mathrm{DM}$ and in this study $12.92 \mathrm{MJ}$ $\mathrm{kg}^{-1}$ in May with no differences between pasture types in both cases).

During the second period, no differences were found in MY and all cows averaged $21.3 \mathrm{~L} \mathrm{~d}^{-1}$ (Table 3). This value was lower than the average MY of the first period $\left(23.8 \mathrm{~L} \mathrm{~d}^{-1}\right)$ given that the cows were at the end of the lactation stage and the lower pasture quality.

\section{Milk solids content}

MF content averaged $4.23 \%$ in May and $3.72 \%$ in June, with no difference between sward types. Similarly, MP content showed no difference between groups, averaging $3.49 \%$ and $3.61 \%$ in May and June, respectively (Table 3). This lack of difference in MF content for HSG compared with PP (non-HSG swards) is consistent with Miller et al. (2001) who found that with a difference of 3.9 percentage points in WSC content between pastures $(12.6 \%$ vs. $16.5 \%) \mathrm{MF}$ content was the same for both groups of cows (4.82\%).

The only milk solid that varied its content between groups was ML; the cows grazing the HSG pasture had higher ML than the cows in the PP in May (Table 3). In June, even though the difference did not reach statistical significance $(p=0.06)$, there was a weak superiority of the PP group over the HSG group. Previous studies have not found a consistent effect of WSC content of pasture on ML from cows grazing contrasting swards, although 
numerical differences were reported (Miller et al., 2001; Taweel et al., 2005). The lower ML in May in the group of cows grazing the PP could be related to the higher SCC observed in this group, possible due to leak out of the alveolus between epithelial cells during an inflammatory process (Shuster et al., 1991). This is consistent with the findings of Kitchen (1981) who reported a reduction in ML with increased SCC in dairy cows.

\section{Somatic cell count}

This variable was analysed on a $\log _{10}$ scale and the results are presented in log scale and back transformed averages (Table 3). In May, SCC was significantly lower, almost half, in the HSG compared with the PP. According to Shook and Seaman (1983), dairy cows between 72,000 and 141,000 cells $\mathrm{mL}^{-1}$ would lose $0.68 \mathrm{~kg}$ of milk production compared with cows below 71,000, which do not show any loss due to SCC. Similarly, Seegers et al. (2003) showed that the effect of SCC on individual cow yield can conservatively be accounted for by a decrease in $0.5 \mathrm{~kg}$ of milk per two-fold increase of SCC starting over 50,000 cells $\mathrm{mL}^{-1}$. The reduction in the SCC of the cows grazing the HSG in May is coincident with the increase in MY, compared with the cows grazing the PP. In June, no difference was observed bet-

Table 3. Predicted means of milk yield and milk composition from cows grazing two different pastures: high sugar grass reseed sward and permanent pasture at the sampling performed on May $4^{\text {th }}$ and June $10^{\text {th }} 2016^{1}$.

Cuadro 3. Promedios predichos de rendimiento de leche y composición de la leche de vacas en pastoreo de dos diferentes praderas: pradera de resiembra de ballica alta en azúcares y pradera permanente en el muestreo realizado el 4 de mayo y 10 de junio $2016^{1}$.

\begin{tabular}{|c|c|c|c|c|c|c|}
\hline & Yield (L cow $\left.{ }^{-1}\right)$ & Milk fat (\%) & Milk Protein (\%) & Lactose (\%) & SCC $\left(\mathrm{x} 1000\right.$ cells $\left.\mathrm{mL}^{-1}\right)$ & LogSCC \\
\hline \multicolumn{7}{|l|}{ May $4^{\text {th }}$} \\
\hline HSG & 24.6 & 4.20 & 3.47 & 4.41 & 59.4 & 1.774 \\
\hline $\mathrm{PP}$ & 22.9 & 4.25 & 3.50 & 4.34 & 113.3 & 2.054 \\
\hline SEM $^{2}$ & $0.333 ; 0.404$ & $0.076 ; 0.066$ & $0.029 ; 0.031$ & $0.017 ; 0.018$ & & $0.034 ; 0.041$ \\
\hline \multicolumn{7}{|l|}{$P$ values } \\
\hline Treatment (T) & 0.005 & 0.625 & 0.743 & 0.007 & & $<0.001$ \\
\hline Lactation (L) & 0.031 & & 0.002 & 0.003 & & 0.023 \\
\hline $\mathrm{BCS}(\mathrm{C})$ & & 0.024 & 0.002 & 0.312 & & \\
\hline \multicolumn{7}{|l|}{$\mathrm{LxT}$} \\
\hline $\mathrm{C} \times \mathrm{T}$ & & 0.023 & & & & \\
\hline $\mathrm{LxC}$ & & & & 0.052 & & \\
\hline \multicolumn{7}{|l|}{$\mathrm{L} \times \mathrm{C} \times \mathrm{T}$} \\
\hline \multicolumn{7}{|l|}{ June $10^{\text {th }}$} \\
\hline HSG & 20.9 & 3.74 & 3.60 & 4.42 & 64.9 & 1.812 \\
\hline PP & 21.7 & 3.71 & 3.62 & 4.48 & 66.4 & 1.822 \\
\hline SEM $^{3}$ & $0.661 ; 0.713$ & $0.059 ; 0.064$ & $0.045 ; 0.043$ & $0.019 ; 0.020$ & & $0.041 ; 0.043$ \\
\hline \multicolumn{7}{|l|}{$P$ values } \\
\hline Treatment (T) & 0.132 & 0.993 & 0.328 & 0.062 & & 0.748 \\
\hline Lactation (L) & 0.633 & 0.014 & & 0.865 & & 0.008 \\
\hline BCS (C) & $<0.001$ & 0.003 & $<0.001$ & 0.483 & & 0.070 \\
\hline $\mathrm{LxT}$ & 0.866 & & & & & \\
\hline $\mathrm{C} \times \mathrm{T}$ & 0.380 & & & & & \\
\hline $\mathrm{Lx} C$ & 0.249 & & & 0.019 & & 0.012 \\
\hline $\mathrm{L} \times \mathrm{C} \times \mathrm{T}$ & 0.043 & & & & & \\
\hline
\end{tabular}

\footnotetext{
${ }^{1}$ All predicted means are based on the mean level of the pre-experimental covariate; ${ }^{2,3}$ Left value is for HSG, right is for PP due to unequal sample sizes.
} 
ween groups, averaging 66,650 cell $\mathrm{mL}^{-1}$, which is under the critical value of 72,000 cells $\mathrm{mL}^{-1}$ suggested by Shook and Seaman (1983) to start having a detrimental effect on milk production.

\section{Productivity of the land}

Regarding pasture productivity, even though it was not measured directly, it can be inferred that the HSG reseeded sward was more productive in terms of DM per hectare than the PP; 5.5 ha were cut for silage in May yielding $6 \mathrm{t} \mathrm{DM} \mathrm{ha}^{-1}$ (total $33 \mathrm{t}$ DM over the 14.1 ha trial fields), whereas no excess pasture was available on the PP swards. Moreover, the HSG pasture supported a greater animal density than the PP, 5 vs. $4.5 \mathrm{LU}$ ha ${ }^{1}$, respectively. This trend is consistent with the work of Hopkins et al. (1990) who found an increase (41\%) of DM production in the first year of a perennial ryegrass reseed sward compared with a permanent pasture, both receiving $150 \mathrm{~kg} \mathrm{ha}^{-1} \mathrm{~N}$ per year. Models developed by Teagasc, Ireland (Shalloo et al., 2011) showed that when the level of reseeding is increased at the farm there is a substantial increase in herbage production, stocking rate and milk production. The model also showed that persistency of the new sward is relevant to maintain the benefits of a reseeded sward on farm profit and system sustainability.

Overall, considering the number of animals grazing each pasture type and the average MY measured in May and June, the herd of 70 cows grazing on the HSG (14.1 ha) was estimated to produce on average $113.8 \mathrm{~L} \mathrm{~d}^{-1}$ $\mathrm{ha}^{-1}$ while the herd of 55 cows grazing the PP (12.1 ha) produced $101.3 \mathrm{~L} \mathrm{~d}^{-1} \mathrm{ha}^{-1}$. During the whole experimental period, considering the days from turnout to end of trial, HSG produced $12.3 \%$ more milk than PP. This overall improvement in land productivity agrees with Shalloo et al. (2011) who predicted that increasing the level of reseeding on farm will increase milk sales by increasing grass production if accompanied by higher stocking rates, as was the case in this case study, even though pasture quality was comparable.

\section{CONCLUSIONS}

In the first year of establishment HSG only showed a greater content of WSC than the PP in one sampling time, which was coincident with the slightly higher MY, ML and the reduced SCC. Despite the lack of difference in pasture quality and associated MY and quality at the cow level the reseeded HSG sward did outperform the PP in our commercial case study as a result of greater DM yield. This resulted in a commercial decision to increase stocking rate ( 5 vs. $4.5 \mathrm{LU} \mathrm{ha}^{-1}$ ), greater DM removal for silage (33 vs. 0 t DM from 14.1 and 12.1 ha, respectively) and ultimately produce more milk per ha (113.8 vs. $\left.101.3 \mathrm{~L} \mathrm{ha}^{-1} \mathrm{~d}^{-1}\right)$ in the HSG over the PP, respectively. Further studies in the following years of the new sward are needed to assess the potential of the HSG for improving dairy grazing systems performance over the long term and whether pasture quality will improve over and above the PP at a farm system level.

\section{ACKNOWLEDGMENTS}

This work was funded as part of the DEFRA Sustainable Intensification Research Platform (SIP1). Support in writing up the work was greatly received by the Biotechnology and Biological Sciences Research Council (BBSRC) through the strategic programmes Soil to Nutrition (S2N; BBS/E/C/000I0320) and Achieving Sustainable Agricultural Systems (ASSIST; BBS/E/ C/000I0130) at Rothamsted Research.

\section{REFERENCES}

Alderman, G., Cottrill, B.R., 1993. Energy and protein requirements of ruminants. CABI Publishing, Wallingford, Oxon, UK.

Association of Official Analytical Chemists (AOAC), 1990. Official methods of analysis of the AOAC, $15^{\text {th }}$ ed. Arlington, Washington DC, USA.

Association of Official Analytical Chemists (AOAC), 2002. Official methods of analysis of AOAC International, $17^{\text {th }} \mathrm{ed}$. Gaithersburg, Md., USA.

Chegini, A., Ghavi, N., Hosseini, H., Shadparvar, A., 2017. Effect of somatic cell count on milk fat and protein in different parities and stages of lactation in Holstein cows. Acta Agriculturae Slovenica, 110(1), 37-45. https://doi.org/ 10.14720/aas.2017.110.1.5

Cosgrove, G., Burke, J., Death, A., Hickey, M., Pacheco, D., Lane, G., 2007. Ryegrasses with increased water soluble carbohydrate: evaluating the potential for grazing dairy cows in New Zealand. Proceedings of the New Zealand Grassland Association 69, 179-185.

Eisler, M., Lee, M., Tarlton, J., Martin, G., Beddington, J., Dungait, J., Greathead, H., Liu, J., Mathew, S., Miller, H., Misselbrook, T., Murray, P., Vinod, V., Van Saun, R., Winter, M., 2014. Steps to sustainable livestock. Nature 507, 32-34. https://doi.org/10.1038/507032a

Food and Agriculture Organization of the United Nations (FAO), 2009. How to feed the world in 2050. Economic and Social Development Department, Rome, Italy, pp. 1-35. http://www.fao.org/fileadmin/templates/wsfs/ docs/expert_paper/How_to_Feed_the_World_in_2050. pdf

Hopkins, A., Gilbey, J., Dibb, C., Bowling, P., Murray, P., 1990. Response of permanent and reseeded grassland to fertilizer nitrogen. 1. Herbage production and herbage quality. Grass and Forage Science 45(1), 43-55. https://doi. org/10.1111/j.1365-2494.1990.tb02181.x

Humphreys, M.O., 1989. Water-soluble carbohydrates in perennial ryegrass breeding. I. Genetic differences among cultivars and hybrid progeny grown as spaced plants. Grass and Forage Science 44(2), 231-236. https://doi. org/10.1111/j.1365-2494.1989.tb01931.x 
Kitchen, B.J., 1981. Bovine mastitis: milk compositional changes and related diagnostic tests. Journal of Dairy Research 48(1), 167-188. https://doi.org/10.1017/ S0022029900021580

Lee, M.R.F., Rivero, M.J., Cone, J., 2018. The role of pasture in the diet of ruminant livestock, in: Marshall, A., Collins, R. (Eds.), Improving grassland and pasture management in temperate agriculture. Burleigh Dodds Science Publishing, Cambridge, UK, «In press».

McGrath, D., 1992. A note on the influence of nitrogen application and time of cutting on water-soluble carbohydrate production by Italian ryegrass. Irish Journal of Agricultural and Food Research 31(2), 189-192. https:// www.jstor.org/stable/25562191

Miller, L.A., Moorby, J.M., Davies, D.R., Humphreys, M.O., Scollan, N.D., MacRae, J.C., Theodorou, M.K., 2001. Increased concentration of water-soluble carbohydrate in perennial ryegrass (Lolium perenne L.): milk production from late-lactation dairy cows. Grass and Forage Science 56(4), 383-394. https://doi.org/10.1046/j.13652494.2001.00288.x

Moorby, J.M., Evans, R.T., Scollan, N.D., MacRae, J.C., Theodorou, M.K., 2006. Increased concentration of water-soluble carbohydrate in perennial ryegrass (Lolium perenne L.). Evaluation in dairy cows in early lactation. Grass and Forage Science 61(1), 52-59. https://doi.org/10.1111/ j.1365-2494.2006.00507.x

Pacheco, D., Burke, J., Cosgrove, G., 2007. An empirical model to estimate efficiency of nitrogen utilisation in cows grazing fresh forages, in: Chapman, D., Clark, D., Macmillan, K., Nation, D. (Eds.), Meeting the challenges for pasturebased dairying. Proceedings of the Australasian Dairy Science Symposium, Melbourne, Australia, pp. 409-416.

Parsons, A.J., Rasmussen, S., Xue, H., Newman, J.A., Anderson, C.B., Cosgrove, G.P., 2004. Some high sugar grasses don't like it hot. Proceedings of the New Zealand Grassland Association 66, 265-271.

Parsons, A.J., Rowarth, J., Rasmussen, S., 2011. High-sugar grasses. CAB Reviews: Perspectives in Agriculture, Veterinary Science, Nutrition and Natural Resources 6(46),
1-12.

Pretty, J., Bharucha, Z.P., 2014. Sustainable intensification in agricultural systems. Annals of Botany 114(8), 15711596. https://doi.org/10.1093/aob/mcu205

Seegers, H., Fourichon, C., Beaudeau, F., 2003. Production effects related to mastitis and mastitis economics in dairy cattle herds. Veterinary Research 34(5), 475-491. https://doi.org/10.1051/vetres:2003027

Shalloo, L., Creighton, P., O'Donovan, M., 2011. The economics of reseeding on a dairy farm. Irish Journal of Agricultural and Food Research, 50(1), 113-122. http://hdl.handle.net/11019/55

Shook, G., Seaman, A., 1983. The new DHI linear score for somatic cell count. Proceedings of the $22^{\text {nd }}$ Annual Meeting National Mastitis Council, Louisville, Kentucky, 2123 February 1983, pp. 31.

Shuster, D.E., Harmon, R.J., Jackson, J.A., Hemken, R.W., 1991. Suppression of milk production during endotoxin-induced mastitis. Journal of Dairy Science 74(11), 3763-3774. https://doi.org/10.3168/jds.S0022-0302(91)78568-8

Søegaard, K., Gierus, M., Hopkins, A., Halling, M., 2007. Temporary grassland - challenges in the future. Proceedings of the European Grassland Federation, Grassland Science in Europe, 3-5 September 2007, Ghent, Belgium, pp. 27-38. http://www.europeangrassland.org/fileadmin/ media/EGF2007_GSE_vol12.pdf

Taweel, H.Z., Tas, B.M., Smit, H.J., Elgersma, A., Dijkstra, J., Tamminga, S., 2005. Effects of feeding perennial ryegrass with an elevated concentration of water-soluble carbohydrates on intake, rumen function and performance of dairy cows. Animal Feed Science and Technology 121 (3-4), 243-256. https://doi.org/10.1016/j. anifeedsci.2005.02.024

Thomas, T.A., 1977. An automated procedure for the determination of soluble carbohydrates in herbage. Journal of the Science of Food and Agriculture 28(7), 639-642. https:// doi.org/10.1002/jsfa.2740280711

Waghorn, G.C., Clark, D.A., 2004. Feeding value of pastures for ruminants. New Zealand Veterinary Journal 52(6), 320 331. https://doi.org/10.1080/00480169.2004.36448 